\title{
THE SUPPLIER RELATIONSHIP PRACTICES OF TRAVEL AGENCIES IN THE WESTERN CAPE PROVINCE - WHAT IS THE STATUS QUO?
}

\author{
Dr. Mornay Roberts-Lombard: University of Johannesburg
}

\begin{abstract}
Purpose: The purpose of the article is to explore the supplier relationship practices of travel agencies in the Western Cape province. The article wants to establish the current supplier relationship practices of travel agencies in the province and to identify limitations in supplier market relationships which might exist in the industry.

Problem investigated: Relationships are the basis on which trade in the travel industry is built (George, 2006:224). The establishment and management of these relationships must be to the advantage of all parties in the relationship (Swart, 2003:120). Townes (2007) indicated that the current level of relationships that exists between travel agencies and their suppliers, especially the South African Airways (SAA), the Protea and Southern Sun hotel groups and motor vehicle rental companies such as AVIS is fragmented and negatively impairs on the ability of travel agents to deliver a quality service to their customers. To improve their overall level of service delivery to both corporate and leisure customers, it is important for travel agencies to know and understand the current level of their relationships with suppliers. It is against this background that the research was undertaken.
\end{abstract}

Methodology: The target population for this study was 118 travel agencies of which 61 managers and/or owners participated through personal interviews in the completion of questionnaires. Data analysis was done by calculating averages and standard deviations, Explorative Factor Analysis (EFA), Cronbach Alpha-values and practical significance by means of effect sizes.

Findings: The owners and managers of travel agencies are of the opinion that the strengthening of their existing relationships with suppliers must be prioritised. More emphasis should be placed on the strengthening of existing communication channels between travel agencies and their suppliers to secure the faster resolution of queries and complaints and to enhance the sharing of information, skills and knowledge between the two parties. The results further indicated that the development of long term relationships with suppliers are important for the future existence of the travel agency industry in the Western Cape. The establishment of these relationships must, however, be to the advantage of both parties in the relationship

Conclusion: Travel agencies and their suppliers should work in collaboration to improve their service delivery to customers by sharing information on product development, marketing and promotional strategies as well as future distribution initiatives. It is also important that both travel agencies and their suppliers should believe in the long term value of establishing a relationship with each other. It is for this reason that trust and commitment are prerequisites for the establishment of such a relationship

\section{Keywords}

Supplier, supplier market, trust, commitment, long term relationships

\section{INTRODUCTION}

The current economic recession, global depressed travel markets as well as maturing domestic markets are creating increasingly competitive conditions for travel channel partners. Competitive pressures encourage suppliers (e.g. airlines, hotel and car rental groups in South Africa) to decrease their investment in traditional channels, find alternative or dual channels of distribution and require distributors to increase their channel investments. These trends have resulted in increased tensions in and the deterioration of channel relationships (Kannan \& Tan, 2006:755-762). Current trends in the travel industry indicate that the majority of suppliers in the airline, hotel and car rental industry in South Africa prefer to stimulate direct on-line sales to eliminate or reduce dependency on intermediaries. The reasons why certain customers prefer to use the internet or go direct to suppliers is complex and multi-faceted and there is no quick fix or one-size-fits-all solution. Reasons could be price competition from the internet, as well as direct supplier sales to customers. This has necessitated the travel retail industry to become far more competitive and bottom-line driven with the result that consultants' value is increasingly being judged by their ability to produce more in less time. Travel consultants - driven by travel agency managers who are under pressure to produce more profit while cutting costs - are now expected to be sales people, experts on an impossible number of products, money 
handlers, technology experts and relationship managers all rolled into one (Viljoen, 2009:8; Bendix, 2008:9). The current threat of direct marketing via the Internet, especially in terms of the distribution of supplier products such as those of South African Airways (SAA), the Southern Sun and Protea hotel groups as well as car rental companies such as Avis Car Rental, requires travel agencies in South Africa to market themselves as a value-adding extension for the products and services of airlines and hotels. These organisations were amongst the first since 1 May 2005 to drive direct marketing sales via their websites, thereby attempting to reduce the role of travel agencies in the distribution of their products. Through the delivery of a quality service to customers and an increase in the sale of airline tickets, hotel rooms and car rentals, the travel agency industry in South Africa can ensure its future existence in a highly competitive market.

The creation and establishment of value-adding, long term relationships with suppliers is necessary for the future existence of an organisation. Such a relationship must be based on the principles of co-operation, trust and commitment which are perceived as core components in the building of long term relationships. The retail travel trade and their suppliers also focus on the establishment of a relationship which is mutually beneficial, mutually interdependent and characterised by two way communication between the parties (Alhabeeb, 2007:609-611). The following factors are important for the retail travel trade in South Africa when creating and establishing a long term relationship with suppliers (Parvatiyar \& Sheth, 2000: 9-12), namely:

- The reliability of the agreement with suppliers;

- The willingness of the supplier to deliver products and services on time; and

- The ability of the supplier to be flexible with deliveries.

In the past, the retail travel trade in South Africa has placed excessive pressure on suppliers to lower the prices of their products and services. This impaired the building of long term relationships with suppliers since it was not built on a win-win situation. By applying the principle of relationship marketing, both the retail travel trade and the supplier attempts to benefit from a long term relationship between them. Through relationship marketing a larger emphasis is placed on co-operation between the two parties. This article will provide a view on the current level of supplier market relationships which exists between the travel agency industry in the Western Cape province and its various suppliers.

\section{LITERATURE OVERVIEW}

In a highly competitive environment a relationship between an organisation and its suppliers of products and services is required. This will empower the organisation to provide its customers with value-added products and services. A meaningful relationship between the organisation and its strategic suppliers can be fundamental to the future success of the organisation (Brink, 2001:282). The relationship between the travel agency and its suppliers will continuously depend on the following principles, namely (Lessing, 2005:8; TIR, 2008:6):

- The quality of the products being delivered by the supplier;

- The quality of the service which suppliers deliver to travel agencies;

- The willingness of suppliers to honour agreements with the travel agency trade;

- The responsiveness of travel agencies to supplier queries; and

- The involvement of travel agencies in supplier product development.

The maintenance of a good relationship with suppliers therefore becomes a prerequisite to ensure that value is delivered to the end users (customers) of the organisation. Researchers in the field of buyer-sellerrelationships emphasise the importance of components such as mutual inter-dependency, trust and commitment to the establishment of a long term relationship between parties (Theodorakioglou, Gotzamani \& Tsiolvas, 2006:149-151). These aspects are highlighted in the different components of supplier markets discussed below.

\section{Value adding components}

Relationship marketing encompass a process whereby a relationship is established between an organisation and its customers and is managed on the basis of co-operation and commitment. The development of such a relationship is based on the following two principles, namely (Petzer, 2005:45): 
- The extent of trust which exist between the individual customer and the organisation; and

- The willingness of the customer to establish a relationship with the organisation or to strengthen an existing relationship with the organisation.

Meaningful and continuous relationships with strategic suppliers can be fundamental to the success of an organisation. The objectives of both parties to the relationship can be achieved through a variety of exchange transactions to establish the relationship and to manage it. Both parties will, however, be committed to the relationship when the availability of alternatives are low and the investment of parties to the relationship is large (Giller \& Matear, 2001:99).

According to Lee, Kwon \& Severance (2007:444-445) suppliers and the retail travel trade (i.e. travel agencies) are inter dependent towards each other when each of the parties have access to resources which the other party needs. Commitment can also be established when the co-operation between parties lead to greater certainty in terms of access to resources or a lower risk for a loss of resources. Uncertainty with regard to the environment can influence the supply of resources and this influence the willingness of organisations to work in collaboration with other organisations. Barnes (2001:288-289) support this argument by stating that positive supplier-customer relationships are influenced by the ability of the supplier to provide the retail travel trade with products and services on time. In addition, it is also influenced by the willingness of the retail travel trade to interact with the supplier with the necessary respect.

The Association of Southern African Travel Agents (ASATA) completed a survey amongst travel agents in South Africa to identify the factors that will increase the value which they attach to the products and services of suppliers. These factors have a direct influence on the marketability of the products and services of the travel agency. An important outcome of this survey was the direct influence of supplier products on the marketability of the travel agency. The factors that the travel agency industry in South Africa value in their relationship building initiatives with suppliers, can be listed as follows (ASATA, 2004):

- The knowledge of travel agency employees;

- The price level of the products and services of the travel agency;

- The availability of airline tickets and hotel accommodation;

- The available alternatives for motor vehicle renting with reference to the motor vehicle companies and motor vehicle renting packages;

- The availability and choice of national and international travel packages; and

- The brand management of the supplier.

The two primary considerations for organisations to enter into a partnership with suppliers is a reduction in costs (financial performance deliverance) and an increase in customer service deliverance (non financial performance). Financial benchmarks refer to return on investment as well as the direct profit percentage on sales. Non financial benchmarks, however, refers to the customer satisfaction levels allocated with the organisation (Mentzer, 2000:471).

Gummesson (2000:37) argue that a sound relationship between parties create a smaller opportunity for a competitor to threaten the consistency of the relationship. In Japan for example it does occur that a new supplier negotiate a contract with an organisation and secure the contract above an existing supplier. Through the stimulation of competition an organisation wants to ensure that the original supplier remains aware of its needs and expectations as well as the reality of competition in the market place.

\section{Long term relationship inclination}

Sin, Tse, Chan, Heung \& Yin (2006:410) argue that when exchange partners have common goals or values, they will be more committed to a relationship with each other. Shared value has long been considered an important dimension in building buyer-seller relationships. Lager (2008:30-32) agrees by stating that the decision of an organisation to establish a long term relationship with a supplier can be influenced by the answers to the following questions, namely (Lager, 2008:30-32): 
- Are suppliers viewed as a source or a potential source of competitive advantage?;

- Must suppliers be more aware of the needs of the organisation?;

- Is the organisation willing to become more aware of the needs of the supplier?;

- Is the organisation willing to view suppliers as partners in the relationship?;

- Is the organisation willing to establish a relationship with suppliers based on honesty and trust?; and

- Does the organisation believe that suppliers will be unsuccessful over the next three years to satisfy their needs with regard to the following?:

- costs;

- quality;

- delivery; and

- design and developmental ability.

Brink (2001:284) emphasise that an organisation must develop a comprehensive understanding of its key business activities to ensure that it will be in a better position to obtain clarity with regard to the type of relationship which it wants to establish with suppliers. It is therefore important for the organisation to do introspection regarding the necessity and importance of establishing a long term relationship with suppliers. The key factor which will determine whether both the supplier and the prospective buyer will establish a relationship is contained in the following question: "Is the supplier or the potential buyer a possible candidate with whom a relationship can be established"? If the answer to this question is positive for both parties, the possibility for the establishment of a relationship is positive.

\section{Strengthening of the relationship with suppliers}

A motivation for an organisation to strengthen its relationship with suppliers is an enlargement in the advantages for both parties due to their closer co-operation (Chenet, Tynan \& Money, 2000:472-595). The satisfaction which the organisation experience with the product or service deliverance of the supplier are influenced by the following factors (Terblanche, 2007:3-4):

- The level of customer satisfaction which the organisation experience during the exchange process;

- The level of trust which the organisation has in the supplier; and

- The level of commitment of the supplier to the relationship.

The expansion of the relationship between the two parties are therefore based on the win-win principle. This principle emphasise the necessity for both parties to add value to the relationship and to receive individual value from the relationship (Terblanche, 2007:3-4). Towers and Ashford (2001:4) state that commitment and trust between a supplier and its customer must be applied to ensure that the relationship between the parties are maintained and expanded over the long term. It provides both parties with the challenge to demonstrate their commitment to and trust in the relationship.

The commitment of the parties to the relationship are influenced by the following three factors, namely (Morris \& Carter, 2005:32-35):

- The advantage that accrue from the relationship;

- The availability of alternative commitments; and

- The comparable advantage of the relationship with an existing one.

From these factors two core principles can be formulated. These principles have a direct influence on the stability of the supplier-customer relationship and can be described as follows (Barnes, 2001:122):

- The degree to which a relationship provides valued outcomes by fulfilling important needs; and

- The comparison level of alternatives, which is based on a quantitative expectation of what a relationship's outcomes should be in an ideal involvement, as well as a comparison of a partner's own outcomes to the other partner's inputs and outcomes.

The establishment and management of long term relationships is a timely process which must be continuously nurtured to ensure its long term survival (Barnes, 2001:118). The stability and expansion of these relationships are, however, determined by the commitment of both partners to being trustworthy and 
loyal and should eventually lead to specific advantages. These advantages accrue due to the willingness of partners in the relationship to forfeit their independence for more mutual dependency and encompass the following (Berndt, 2009:320-332):

- An increase in cost savings by both parties;

- An improvement in the quality of delivered services and products;

- The design cycle times for products are reduced between $20 \%$ and $75 \%$;

- An increased value addition to an organisation;

- Competitive advantage in the field of technology for both parties; and

- More meaningful and competitive organisational strategies can be formulated by both parties.

\section{Viability of establishing long term relationships with suppliers}

This refers to the values and inclination of both parties towards the relationship. It includes both an investigative and experimental approach to relationship based on exchange transactions. Both parties consider the commitments, advantages, limitations as well as the possibility of exchange which come forth from the relationship (Fink, Edelman \& Hatten, 2007:31-32). Po-Chedley (2001:12) specify that an organisation must consider the following factors when determining the viability of establishing a relationship with a supplier:

- The professional inclination of the supplier with regard to the personal grooming of employees, the appearance of physical facilities as well as the communication ability and positive approach of employees;

- The availability and reaction of suppliers. This aspect includes the speed at which enquiries are addressed;

- An understanding of the expectations of customers. The supplier must follow a comprehensive approach to understand the needs and preferences of an organisation;

- The knowledge of the supplier regarding the product or service to be supplied to an organisation; and

- The management of customer centric problems. The supplier must resolve problems which can influence the functioning of its customer negatively.

The service orientation of suppliers also has an important influence on the establishment of a relationship between the relevant parties. If the supplier can deliver a service to an organisation that will satisfy its needs, loyalty towards the supplier is ensured. The disbanding of a relationship between the supplier and the buyer can be approached from two perspectives, namely (Kannan \& Tan, 2006: 755-763):

- Perspective 1. It refers to a process where one partner distance himself from the other partner or end the relationship; and

- Perspective 2. It emphasises that the disbanding of the relationship starts when one of the partners decide that the cost to continue with the relationship outweighs the advantages thereof.

The reality of disbanding is emphasised when the principles of trust and service deliverance are questioned by one of the partners in the relationship (Towers \& Ashford, 2001:5). The establishment of a relationship that is built on the principles of trust and commitment is a timely and expensive process. The disbanding of the relationship also becomes progressively more expensive as the relationship develops. It can therefore be argued that the relationship between parties must be based on mutual support for each other. If this is not the case, the possibility of disbanding the relationship becomes a reality which holds cost implications for both parties (Theodorakioglou, Gotzamani \& Tsiolvas, 2006:149-151). Hung \& Chiu (2006:156-158) state that the following factors could contribute to the disbanding of a relationship between two parties, namely:

- The quality of service deliverance by both parties;

- The level of communication between parties;

- The receptiveness of parties towards each others' inputs;

- The time span for taking responsibility towards each other;

- The level of support provided for the solution of problems; and

- The enthusiasm of the parties towards the relationship. 
The above discussion emphasised that the establishment and management of a long term relationship requires the inputs of both parties to the relationship. The disbanding of a relationship can, however, be the decision of only one of the partners to a relationship.

\section{PROBLEM STATEMENT}

Relationships are the basis on which trade in the travel industry is built (George, 2006:224). The establishment and management of these relationships must be to the advantage of all parties in the relationship (Swart, 2003:120). Townes (2007) indicated that the current level of relationships that exists between travel agencies and their suppliers, especially the South African Airways (SAA), the Southern Sun and Protea hotel groups and motor vehicle rental companies such as Avis Car Rental is fragmented and negatively impairs on the ability of travel agents to deliver a quality service to their customers. To improve their overall level of service delivery to both corporate and leisure customers, it is important for travel agencies to know, understand, manage and strengthen the current level of their relationships with suppliers.

Limited research has been conducted in the field of supplier relationship practices in South Africa, and no study has focused exclusively on the relationship marketing practices of travel agencies in the Western Cape province. Prior research within South Africa, as well as internationally, included studies conducted for the purpose of investigating the supplier market practices in the manufacturing and building industries of the North West and Gauteng provinces. The primary focus of previous studies was to provide a holistic view of supplier relationship practices in a manufacturing and building environment or to provide a comparative analysis between academic and practitioner views on the topic. This article will provide a discussion on supplier relationship practices from a service industry perspective which will be beneficial to the travel agency industry in the Western Cape province. The results and conclusions drawn may be used to ensure higher levels of supplier relationship building in the travel agency industry in South Africa, guided by the four constructs developed for the study. The findings of this article could also create a greater awareness among South African travel agencies of the different value adding components that they need to focus on to establish or strengthen a relationship with suppliers. It could further empower travel agencies with the knowledge to determine the viability of establishing a long term relationship with a supplier. It is therefore proposed that this article will contribute to the theoretical and empirical knowledge on supplier relationship building in the travel agency industry in South Africa.

The travel agency industry in South Africa is competitive and sales driven. The current global economic recession and increased competition for a shrinking South African travel market necessitates travel agencies even more to retain their current customer base, which can only be achieved through successful service delivery. The establishment of strategic relationships with suppliers and the strengthening of such relationships provides travel agencies with improved access to these suppliers to obtain information on new product developments, to lodge queries and enquiries and expect the professional management thereof. Through this process, the needs and wants of customers can be better served to ensure that travel agencies can retain their current customers and successfully recruit new ones. The relationship that travel agencies have with their customer base (existing and new) will continuously depend on the relationship between the travel agency and its suppliers. Therefore it becomes important for the travel agency industry in the Western Cape to establish strong relationships with suppliers which could be to the benefit of both the travel agency industry and their suppliers in the long term.

Against the brief background on the importance of supplier relationship building and the travel agency industry provided above, the problem statement of this article is as follows:

To investigate the supplier relationship practices of travel agencies in the Western Cape province.

More formally, the research seeks to establish the current supplier relationship practices of travel agencies in the Western Cape province and to identify limitations in supplier market relationships which might exist in the travel agency industry. The measurement of the supplier market relationships of travel agencies in the Western Cape province was done according to four constructs that were developed from the literature. These 
constructs are value adding components, long-term relationship inclination, strengthening of the relationship with suppliers, and the viability of establishing long term relationships with suppliers.

\section{OBJECTIVES OF THE STUDY}

The purpose of the study is supported by the following objectives, namely:

- To explore the supplier markets of travel agencies in the Western Cape province;

- To identify the value-adding components which travel agencies in the Western Cape province build into their relationship strategies with suppliers;

- To establish whether travel agencies in the Western Cape province are inclined to establish long-term relationships with their suppliers;

- To establish whether travel agencies in the Western Cape province are inclined to strengthen their current relationships with suppliers; and

- To determine if travel agencies in the Western Cape province research the viability of a long term relationship with suppliers before such a relationship is established.

\section{METHODOLOGY}

\section{Research approach}

This study made use of a quantitative research approach and applied the descriptive research technique. Descriptive research empowers the researcher to investigate the research problem with greater clarity and to measure the stated objectives more successfully (Coldwell \& Herbst, 2004:9). The study was also crosssectional, since the respondents were only interviewed once.

\section{Research method Population}

The population for this study included all the travel agents registered with the Association of South African Travel Agents (ASATA) in the Western Cape province. The target population for this study was 118 travel agencies of which 61 participated in the completion of questionnaires. In terms of the small size of the population, it was decided to conduct a census. A response rate of $53 \%$ was obtained for this study.

\section{Research instrument}

The empirical research component of the study consisted of the completion of structured questionnaires through personal interviews. The questionnaire consisted of a structured format and incorporated two types of questions, namely closed-ended questions to gather demographic data on the profile of the travel agency and five point Likert-type statements to test respondent's current and ideal application of identified relationship marketing principles in the supplier markets of travel agencies.

\section{Data gathering}

Personal interviews were conducted with the managers and/or owners of travel agencies in the Western Cape province. A time frame of forty five days were used to complete the interviews. To ensure the participation of the maximum number of population elements, interviews were arranged on the premises of the travel agency. After completion of the interviews, follow-up telephone interviews were done amongst twenty five percent of the respondents. The purpose of these interviews was to determine the accuracy of the information on the questionnaire. Through this process the reliability of the information on the questionnaire was enhanced.

\section{Data analysis}

The statistical software package SAS System for Windows Release, 2002-2005: Version 9.1 Edition; SAS OnlineDoc, 2005: Version 9.1 was used for the analysis of the gathered data. The following analysis was done:

- Means of differences between the ideal and the current application of relationship marketing practices by travel agencies towards their suppliers were calculated; 
- Standard deviations for individual items on the questionnaire were calculated;

- Explorative factor analysis to determine the validity of the questionnaire as a measuring instrument. Table 1 illustrate that according to the MINEIGEN criterion, 1 factor was retained for each of the supplier market $e$.

Table 1

Results of the Exploratory Factor Analysis

\begin{tabular}{|l|l|l|l|}
\hline \multicolumn{1}{|c|}{ Construct } & $\begin{array}{c}\text { Number of factors } \\
\text { retained } \\
\text { according to the } \\
\text { MINEIGEN - } \\
\text { criterion }\end{array}$ & $\begin{array}{c}\text { Cumulative } \\
\text { variance } \\
\text { declared }\end{array}$ & Communalities \\
\hline Value adding components & $\mathbf{1}$ factor retained & $60,38 \%$ & $42,03 \%-74,23 \%$ \\
\hline Long term relationship inclination & $\mathbf{1}$ factor retained & $67,17 \%$ & $55,90-78,14 \%$ \\
\hline $\begin{array}{l}\text { Strengthening of the relationship } \\
\text { with suppliers }\end{array}$ & $\mathbf{1}$ factor retained & $68,20 \%$ & $51,50-79,03 \%$ \\
\hline $\begin{array}{l}\text { Viability of establishing long term } \\
\text { relationships with suppliers }\end{array}$ & $\mathbf{1}$ factor retained & $66,49 \%$ & $58,21 \%-75,08 \%$ \\
\hline
\end{tabular}

- Cronbach's Alpha-values to determine the reliability of the questionnaire as a measuring instrument. The calculation of Cronbach's Alpha-values was done for each supplier relationship construct. Hocking, Stacks \& McDermott (2003:131) indicate that Cronbach's Alpha-values determine the consistency according to which respondents answered the different items on the questionnaire. Table 2 illustrates the Cronbach Alpha-values which was calculated for the four supplier relationship constructs. Since all the Cronbach's Alpha values are 0.75 and higher the questionnaire can be regarded as a reliable instrument (Ellis \& Steyn, 2003:51; Hocking et al., 2003:132).

Table 2

Cronbach Alpha-values for the supplier relationship constructs

\begin{tabular}{|l|l|}
\hline \multicolumn{1}{|c|}{ Construct } & \multicolumn{1}{|c|}{ Cronbach's Alpha value } \\
\hline Value adding components & 0.88 \\
\hline Long term relationship inclination & 0,83 \\
\hline Strengthening of the relationship with suppliers & 0,75 \\
\hline $\begin{array}{l}\text { Viability of establishing long term relationships with } \\
\text { suppliers }\end{array}$ & 0,75 \\
\hline
\end{tabular}

- Practical significance by means of effect sizes. The d-values of Cohen was used for this purpose. This study did not make use of inferential statistics ( $p$-values), but applied the d-values of Cohen to calculate effect sizes. The effect sizes indicate the practically significant differences between the current application of the items in the questionnaire and what the ideal application of the items should be. Effect sizes (dvalues) were calculated by using the following formula (Steyn \& Ellis, 2006: 172-175; Cohen, 1988: 20-27):

$$
d=\frac{\left|\bar{x}_{1}-\bar{x}_{2}\right|}{s_{\max }}
$$

where:

- $\mathrm{d}=$ the effect size;

- $\bar{x}_{1}-\bar{x}_{2}$ is the difference between the current situation (a-value) and the ideal situation (b-value) (e.g. respondents had to indicate on a Ilkert scale of 1-5 how they currently experience a specific scenario, through a statement on the questionnaire, and how they want to experience it as an ideal scenario; and 
- $s_{\max }$ is the maximum standard deviation of the two comparable groups.

Ellis \& Steyn (2003:52) specify below the cut-off points which can be used when interpreting effect sizes:

- If $d \approx 0,2$, it indicates a small effect;

- If $d \approx 0,5$, it indicates a medium effect; and

- If $d \approx 0,8$ or is larger, the effect is both large and practically significant.

\section{MAJOR FINDINGS}

The supplier relationship practices of travel agencies in the Western Cape was measured according to four constructs, namely value adding components, long term relationship inclination, strengthening of the relationship with suppliers and the viability of establishing long term relationships with suppliers. Each of these constructs was statistically analysed to provide information on the averages between the items for (a) the current application of supplier marketing practices and (b) the ideal implementation of supplier marketing practices on the questionnaire, the standard deviation and the effect size. Table 3 also provides an indication of the total number of respondents ( $n$ ) who participated in the study.

Table 3

Constructs for supplier market relationships

\begin{tabular}{|l|l|l|l|l|l|}
\hline \multicolumn{7}{|c|}{ Supplier market constructs } \\
\hline & $\mathbf{n}$ & $\begin{array}{c}\text { Average } \\
(\mathbf{a}) \\
{[\mathbf{x}(\mathbf{a})]}\end{array}$ & $\begin{array}{c}\text { Average } \\
\mathbf{( b )} \\
{[\mathbf{x}(\mathbf{b})]}\end{array}$ & $\begin{array}{c}\text { Maximum } \\
\text { standard } \\
\text { deviation }\end{array}$ & $\begin{array}{c}\text { Effect size } \\
\mathbf{( d )}\end{array}$ \\
\hline Value adding components & 61 & 4,14 & 4,56 & 0,67 & 0,68 \\
\hline $\begin{array}{l}\text { Long term relationship } \\
\text { inclination }\end{array}$ & 61 & 4,27 & 4,59 & 0,61 & 0,54 \\
\hline $\begin{array}{l}\text { Strengthening of the } \\
\text { relationship with suppliers }\end{array}$ & 61 & 3,77 & 4,55 & 0,87 & 0,79 \\
\hline $\begin{array}{l}\text { Viability of establishing long } \\
\text { term relationships with suppliers }\end{array}$ & 61 & 4,09 & 4,38 & 0,82 & 0,51 \\
\hline
\end{tabular}

\section{Value adding components}

The owners and managers of travel agencies $(n=61)$ view their current application of the components which add value to their relationships with suppliers as good $[x(a)=4.14]$. However, they view the ideal application of these components higher $[x(b)=4.56]$. The medium effect size $(d=0,68)$ illustrate that the owners and managers of travel agencies would prefer that the components which add value to their relationships with suppliers be better implemented. These components includes the establishment or strengthening of trust between the travel trade and suppliers since trust is an integral part of any relationship, an improvement in the level of service delivery by suppliers in the airline, hotel and car rental industry to travel agencies in the Western Cape, the strengthening of existing communication channels between suppliers and travel agencies to secure the faster resolution of queries and complaints and to enhance the sharing of information, skills and knowledge between the two parties. The final component that requires improvement is the enhancement of value that flows from the relationship between suppliers and the retail travel trade. Such value should be to the benefit of both parties to secure the continuation and strengthening of the relationship.

\section{Long term relationship inclination}

The owners and managers of travel agencies $(n=61)$ indicated a long term inclination towards establishing a relationship with their suppliers $[x(a)=4,27]$. They are, however, of the opinion that the long term nature of their relationship building inclination can be further developed $[x(b)=4,59]$. The medium effect size $(d=0,54)$ illustrate that the owners and managers of travel agencies would prefer to develop their long term relationship building inclination towards suppliers further. This, however, will depend on the level of trust that exist between the parties during the initiation and management of the relationship. The more active suppliers such 
as airlines, hotels and car rental groups drive their direct marketing campaigns to exclude travel agencies from their distribution channels, the less willing the latter will be to establish, continue or strengthen a relationship with suppliers. Considering this, the results do indicate that both the travel agency industry and suppliers to the travel trade realise that a mutual, beneficial relationship is necessary to ensure their survival. The travel trade requires the products and services of suppliers to secure an existence and suppliers need travel agencies as an extension of their distribution channel into the South African market. Through such an extension, suppliers are empowering themselves to gain market share faster and with increased success.

\section{Strengthening of the relationship with suppliers}

The owners and managers of travel agencies $(n=61)$ indicated that their relationships with suppliers are strong and that suppliers are attempting to strengthen their relationships with travel agencies $[x(a)=3,77]$. They are, however, of the opinion that this relationship can, ideally, be further strengthened $[x(b)=4,55]$. The practical significant effect size $(d=0,79)$ indicate that the owners and managers of travel agencies are of the opinion that the strengthening of the relationship between themselves and their suppliers must be prioritised.

\section{Viability of establishing long term relationships with suppliers}

The owners and managers of travel agencies $(n=61)$ indicated that they are evaluating the viability of a relationship with their suppliers by focusing on specific factors $[x(a)=4.09]$. They are, however, of the opinion that they must consider these factors more definitely $[x(b)=4.38]$. The medium effect size $(d=0,51)$ indicated that the owners and managers of travel agencies must provide a stronger focus on determining the viability of establishing a long term relationship with suppliers.

The findings of the stipulate that it becomes continuously important for travel agencies to build long term relationships with the suppliers of their products. This can be achieved by allowing suppliers to become more involved in the product mix and promotional campaigns of travel agencies. Suppliers furthermore need to become more aware of the prominent role of travel agencies as a distribution channel for their products and services. The lack of trust which currently exist between travel agencies and suppliers such as the South African Airways (SAA), the Protea and Southern Sun hotel groups and motor vehicle rental companies such as AVIS is hampering the ability of travel agencies to build long term relationships with these suppliers. There is a clear need amongst travel agencies in South Africa to receive greater recognition for their role as prominent distributors of travel products in the country. By supporting the promotional and sales initiatives of travel agencies more directly and reducing their (suppliers) direct distribution and marketing strategies to the public, the listed suppliers above will be able to establish a relationship with travel agencies which will be built on trust.

\section{MANAGERIAL IMPLICATIONS}

A good relationship between the organisation and its suppliers is required within a competitive environment. This will empower the organisation to provide products and services which will add value to its customers. A meaningful relationship between the organisation and strategic suppliers can be fundamental to the future success of the organisation (Brink, 2001:282). The implementation of supplier market activities within the travel agency industry in the Western Cape province can therefore be accommodated more successfully by focusing on the following aspects:

\section{Value adding components}

The literature specify that meaningful and continuous relationships with strategic suppliers can be fundamental to the success of an organisation. The development of such a relationship is based on the extent of trust which exist between the individual customer and the organisation and the willingness of the customer to establish a relationship with the organisation or to strengthen an existing relationship with the organisation (Petzer, 2005:45; Giller \& Matear, 2001:99).

This study is in agreement with the literature (refer to the theory on supplier markets above) and found that trust is a core component to ensure the establishment of a relationship or the extension of a current relationship. It is therefore important that travel agencies and their suppliers should work in collaboration to 
improve their service delivery to customers by sharing information on product development, marketing and promotional strategies as well as future distribution initiatives. Special offers which suppliers such as SAA, the Protea and Southern Sun hotel groups and Avis Car Rental are providing to customers directly via the internet, must also be made available to travel agencies at the same price. This will install trust in the relationship which travel agencies have with these suppliers since both the provision and receipt of value is the foundation of a good relationship between parties.

\section{Long term relationship inclination}

It is the responsibility of a potential buyer to do introspection regarding the necessity and importance of establishing a long term relationship with suppliers. The supplier and the potential buyer need to establish whether they are possible candidates for each other with whom a relationship can be established. The literature states that if the outcome of such a search is positive, the possibility for the establishment of a relationship is positive (Lager, 2008:30-32; Brink, 2001:284). The findings of the study agree with the literature and stipulate that it is important that both travel agencies and their suppliers should believe in the long term value of establishing a relationship with each other. It is for this reason that trust and commitment are prerequisites for the establishment of such a relationship. It is therefore important for suppliers to allocate staff to their call centers which will exclusively address the queries and complaints of travel agencies.

Service centers can be established which will primarily deal with the daily challenges faced by travel agencies in terms of aspects such as the cancellation and refunding of tickets, promotional items advertised, but not available, as well as complaints that deals with incorrect and/or over bookings. It is imperative that the service centers of suppliers (especially the national carrier SAA), the larger hotel groups such as Protea and Southern Sun hotels and car rental companies such as Avis Car Rental also provide travel agents with walkin access to their service centers one day in the week. Such an arrangement must be negotiated between the management of the different suppliers and ASATA, as the representative body of travel agencies in South Africa, to ensure that both parties stand loyal to a signed agreement.

In addition, the study further concluded that travel agencies must inform their suppliers more specifically about their prominent function within the distribution channel of supplier products and services. The establishment of trust is therefore central to ensure a long term commitment between the parties. It is however important that the facilitation of trust be done within the context of continuous communication between the parties to the relationship.

\section{Strengthening of the relationship with suppliers}

The expansion of a relationship between a supplier and a buyer must be based on the win-win principle. This principle emphasise the necessity for both parties to add value to the relationship and to receive individual value from the relationship (Terblanche, 2007:3-4; Towers \& Ashford, 2001:4). The outcome of the research agree with the stated literature by emphasising that travel agencies should focus more on relationship building activities rather than supplier evaluation criteria when establishing a relationship with a supplier. Relationship building activities is more conveniently applied in an environment where suppler market relationships are characterised by a partnership approach.

In addition, the research indicated that suppliers would also need to provide more specific guidance in strengthening the competitive position of travel agencies. This can be achieved by creating and establishing open communication channels with travel agencies to encompass certain aspects. These aspects include the fast resolving of queries and complaints, the continuous determination of the needs of travel agents, the acceptance of suggestions, product innovation as well as improved service delivery to travel agencies.

\section{Viability of establishing long term relationships with suppliers}

It is stated by the literature that the service orientation of suppliers has an important influence on the establishment of a relationship between the relevant parties. If the supplier can deliver a service to an organisation that will satisfy its needs, loyalty towards the supplier is ensured (Theodorakioglou, Gotzamani \& Tsiolvas, 2006:149; Lee, Kwon \& Severance, 2007:444-446; Po-Chedley, 2001;12). The outcome of this research study is in accordance with the literature and indicate that the stability of a relationship between the 
travel agency and a supplier is determined by the manner in which the supplier manages the relationship. It is therefore imperative that the management of travel agencies should also incorporate the opinions of suppliers more regularly in terms of their product development. It is recommended that the management of travel agencies should, in the future, focus more on building relationships with a small, strategic number of suppliers to ensure that value is added to the daily functioning of their businesses. This will ensure that the travel agency industry secures long-term relationships with strategic suppliers which will add positive value to their market growth, competitiveness and ability to improve on their customer satisfaction levels.

\section{SUMMARY}

Competitive forces are putting organisations under pressure to improve quality, delivery performance and responsiveness while simultaneously reducing costs. In response, organisations are increasingly exploring ways to leverage their supply chains and in particular, to systematically evaluate the role of suppliers in their activities. At an operational level, the benefit for an organisation to develop close relationships with key suppliers comes in the form of improved quality or service delivery cost or some combination thereof (Kannan \& Tan, 2006:755-756). Organisations are also increasingly adopting a supply-chain philosophy referred to as relationship marketing, in response to maturing markets, globalisation and greater competition. This approach to managing supply-chain relationships views customer relationships as key assets of the organisation which allows them to maintain and increase sales among their most profitable customers and to improve communication and better co-ordinate buyer-supplier relationships. These buyer-seller relationships, characterised by relatively long-term time horisons, non-market modes of governance and high levels of commitment and trust have been viewed as a "durable basis for competitive advantage" (Morris \& Carter, 2005:32).

This article provided a theoretical perspective on the supplier markets of travel agencies in the Western Cape province. It was followed by a discussion on the findings of the study. These findings concluded that the relationships between travel agencies and their suppliers are fragmented. The direct marketing initiatives of SAA, hotel groups such as the Southern Sun and Protea hotels as well as the Avis Car Rental group are putting strain on the current relationship between travel agencies and these suppliers. The article concluded with a focus on the managerial implications of the findings. A primary managerial implication of the study was that travel agencies and their suppliers should work in collaboration to improve their service delivery to customers by sharing information on product development, marketing and promotional strategies as well as future distribution initiatives.

\section{REFERENCES}

Alhabeeb, M.J. 2007. Consumer trust and product loyalty. International Journal of Consumer Studies, 31:609612.

Asata. 2004. Value Add per Category. [Available on Internet:] http:// www.asata.co.za/downloads/ASATA Consultant Survey Response 04.x/s [Date of use: 24 November 2004].

Bendix, M. 2008. Relationship building needed to put "people back into travel". Travel Industry Review, 159:120, June.

Berndt, A. 2009. Relationship-building strategies. (In: Jooste, C.J., Strydom, J.W., Berndt, A. \& du Plessis, P.J. Applied Strategic Marketing. Sandton: Heinemann, pp. 320-332).

Brink, A. 2001. Strategies for building relationships with key stakeholders. (In: Du Plessis, P.J., Jooste, C.J. \& Strydom, J.W. Applied strategic marketing. Sandown: Heinemann, pp.257, 259-263,273-277,282,284,290).

Chenet, P., Tynan, C. \& Money, A. 2000. The service performance gap: Testing the redevelopment causal model. European Journal of Marketing, 34(3/4):472-495.

Cohen, J. 1988. Analysis for the behavioural sciences. Second edition. Hillsdale, N.J: Earlbaum. 
Coldwell, D. \& Herbst, F. 2004. Business Research. Cape Town: Juta \& Co., Ltd.

Ellis, S.M. \& Steyn, H.S. 2003. Practical significance (effect sizes) versus or in combination with statistical significance (p-values). Managament Dynamics: Contemporary Research, 12(4): 51-53.

Fink, R.C., Edelman, L.F. \& Hatten, K.J. 2007. Supplier performance improvements in relational exchanges. Journal of Business \& Industrial Marketing, 22(1):29-40.

George, R. 2006. Marketing South African Tourism ( $2^{\text {nd }}$ edition). Cape Town: Oxford University Press.

Giller, C. \& Matear, S. 2001. The termination of inter-firm relationships. Journal of Business and Industrial Marketing, 16(2): 94-112.

Gummesson, E. 2000. Total Relationship Marketing. Rethinking Marketing Management: From 4P's to 30R's. Oxford: Butterworth-Heinemann.

Hocking, J.E. Stacks, D.W. \& McDermott, S.T. 2003. Communication research. Boston: A\& B publishers.

Hung, H. \& Chiu, C. 2006. Exploring Customer Satisfaction, Trust and Destination Loyalty in Tourism. The Journal of American Academy of Business, 10(1): 156-159.

Kannan, V. R. \& Tan, K.C. 2006. Buyer-supplier relationships: The impact of supplier selection and buyersupplier engagement on relationship and firm performance. International Journal of Physical Distribution and Logistics Management, 36(10):755-775, July.

Lager, M. 2008. Fine-tuning the channel. CRM Magazine: 30-33. January.

Lee, C.W., Kwon, 1.G., Severance, D. 2007. Relationship between supply chain performance and degree of linkage among supplier, internal integration, and customer. Supply Chain Management: An International Journal, 12(6): 444-452.

Lessing, V. 2005. The dawning of the age of zero commissions is nigh. Travel Industry Review, 118:1-20, January.

Mentzer, J.T. 2000. Supplier Partnering. (In: Sheth, J.N. \& Parvatiyar, A. Handbook of Relationship Marketing. California: Sage Publications, Inc. p.471.)

Morris, M. \& Carter, C.R. 2005. Relationship Marketing and Supplier Logistics Performance: An Extension of the Key Mediating Variables Model. The Journal of Supply Chain Management. Fall.

Parvatiyar, A. \& Sheth, J.N. 2000. Relationship Marketing in Consumer Markets: Antecedents and Consequences. (In: Sheth, J.N. \& Parvatiyar, A. Handbook of Relationship Marketing. California: Sage Publications, Inc. pp. 8-9, 11-12.).

Petzer, D. 2005. Customer retention management for the hotel industry in Gauteng. Potchefstroom: North West University. (Dissertation - PhD) 393 p.

Po-Chedley, D.A. 2001. Client Relationship Management - How to turn client relationships into a competitive advantage. Amherst, Massachusetts: Human Resource Development Press, Inc.

Sin, L.Y.M., Tse, A.C.B., Chan, H., Heung, V.C.S. \& Yin, F.H.K. 2006. The effects of relationship marketing orientation on business performance in the hotel industry, Journal of Hospitality and Tourism Research, 30(4): 407-426. 
Steyn, H.S. \& Ellis, S.M. 2006. Die gebruik van effekgrootte-indekse by die bepaling van praktiese betekenisvolheid. Suid-Afrikaanse Tydskrif vir Natuurwetenskap en Tegnologie, 25(3): 172-175.

Swart, C. 2003. Marketing, Public Relations and Relationship Marketing. (In: Rensburg, R.S. \& Cant, M. Public Relations - South African Perspectives. Sandown: Heinemann. p. 120.)

Theodorakioglou, Y., Gotzamani, K. \& Tsiolvas, G. 2006. Supplier management and its relationship to buyers' quality management. Supply Chain Management: An International Journal, 11(2): 148-159.

Terblanche, N.S. 2007. Customer commitment to South African fast food brands: An application of the Conversion Model. Management Dynamics, 16(2): 2-15.

TIR. 2008. Supplier failure push clients back to agents. Travel Industry Review, 163:1-24, October.

Townes, M. 2007. Personal interview with author. Durbanville. (Cassette recording in the possession of the author).

Towers, N. \& Ashford, R. 2001. The Supply Chain Management of Production Planning and Sustainable Customer Relationships. Management Research News, 24(12): 1-6.

Viljoen, A. 2009. Suppliers will continue reducing rates. Travel Industry Review, 165:1-16, January. 